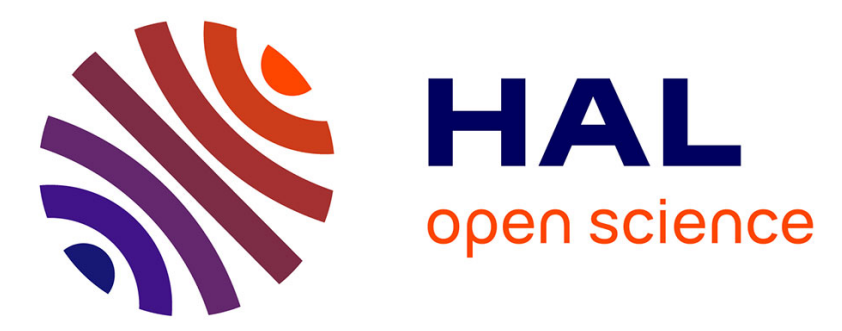

\title{
Diffusing marketization: competition, synergies, and repartition of tasks in the global agri-food policy field
}

Eve Fouilleux

\section{To cite this version:}

Eve Fouilleux. Diffusing marketization: competition, synergies, and repartition of tasks in the global agri-food policy field. David Dolowitz, Magdaléna Hadjisky and Romuald Normand. Shaping Governance in an Era of Globalization Micro-Politics in International Organizations:, Edward Elgar Publishing, pp.15-34, 2020, 10.4337/9781788976992.00008 . hal-02910141

\section{HAL Id: hal-02910141 \\ https://hal.science/hal-02910141}

Submitted on 31 Jul 2020

HAL is a multi-disciplinary open access archive for the deposit and dissemination of scientific research documents, whether they are published or not. The documents may come from teaching and research institutions in France or abroad, or from public or private research centers.
L'archive ouverte pluridisciplinaire HAL, est destinée au dépôt et à la diffusion de documents scientifiques de niveau recherche, publiés ou non, émanant des établissements d'enseignement et de recherche français ou étrangers, des laboratoires publics ou privés. 
Diffusing marketisation. Competition, synergies and repartition of tasks in the global agrifood policy field

Eve Fouilleux, CNRS-LISIS, CIRAD-MOISA

\begin{abstract}
Through an exploration of the global agrifood policy field, we argue that global public policymaking points to a clear and relatively strict division of labour between international organizations. We describe four interconnected concomitant processes contributing to the diffusion and hegemony of the market referential in this field. The first one is the dissemination process of orthodox economic ideas by the World Bank and the OECD, notably through the lenses of the close relationship they foster with academic economics. Second, beside this 'soft' diffusion of ideas, 'hard' imposition mechanisms apply (WTO rules, World Bank loans). Third, sectoral international organizations, such as the FAO, appear unable to define their own path for policies. Their policy work is either directly or indirectly supervised by the former organizations. The fourth is a privatization process, through growing transnational private regulation, which further deepen the marketization process at stake through its use of voluntary standards.
\end{abstract}

\title{
Key-words
}

agri-food policy, global policy, international organization, policy ideas, policy forum, policy arena, FAO 


\section{Introduction}

What role do international organizations play in the formulation and spread of the market referential in the case of agri-food policies around the globe? In this, how do power relations between international organizations influence global policy making in agri-food? And, what role do private actors play in these processes?

This chapter seeks to answer these questions ${ }^{\mathrm{i}}$. In this, we consider international organizations as complex collective constructs, who's authority depends on their ability to make intelligible and manageable policy problems (and elaborate corresponding policy solutions), and whose inner logic partially depends on the interests and initiatives of external public and private actors. We take particularly seriously the third hypothesis offered in Chapter 1, and emphasize the impact these relations have on the definition of global policy problems and the formulation of policy solutions. Indeed, we think that understanding global agri-food policies requires not only a focus on one or another active or specialized organization, but also the micro sociological processes at stake among the organizations involved in this. In this chapter, we argue that these relations fundamentally shape the dynamics at stake in the global agri-food policy.

To understand how ideas and meanings evolve in the field of agri-food policies and how they result in a specific problematization, one needs to analyze the interplay of existing organizations and institutions and the power balances within the network of actors involved in the field (Hoffman 1999, p. 352). We will give a careful attention to the microprocesses at stake in global agri-food policies, including the diffusion of unified policy prescriptions and the growing importance of transnational and international arenas in the shaping what is considered 'legitimate knowledge' in national agri-food policies. 
This will allow us to understand the relational mechanisms through which the agrifood global policy field is shaped by the 'market frame'. Such a frame can be seen as a system which is grounded in a neoliberal ideology, but one which is a translated into the actual policy content and instruments of public action (Muller 2005, p. 173). Similarly, Marie-Laure Djelic et Kirstin Sahlin-Andersson (2006) talk about marketization to refer

both to market ideologies and market oriented reforms. A market ideology reflects the belief that markets are of superior efficiency for the allocation of goods and resources. In its most extreme form, this belief is associated with the commodification of nearly all spheres of human life. Market-oriented reforms are those policies fostering the emergence and development of markets and weakening, in parallel, alternative institutional arrangements. (53)

The marketisation frame has become particularly prevalent in the agri-food sector since the 80 s and has led a deep reform process over the past 20-years around the globe. This notably materializes through international trade; as the main means and ultimate end of socioeconomic development. Consequently, the marketisation frame is the dominant structuring perspective for domestic agri-food policies. It also refers to a dramatic rise in market-based private governance devices in the field.

The idea behind this chapter is not to delimit or mechanically analyse global public policy cycles and their various stages (agenda-setting, policy-transfer and decision-making, implementation, monitoring and evaluation) as sometimes suggested (Stone 2008), or even discuss the existence of such elements. The objective is to qualitatively explore how the market referential shapes current agri-food policy debates at the global level. This points to a diversity of actors, activities, and processes marked by specific power relations. We show, marketisation responds to specific and 'stable-in-time' hierarchies, which define specific 
organization/structuration of the global agri-food policy field, i.e. specific interactions among public, private, international, transnational, organizations and all sorts of actors in the field, including direct and indirect constraints as well as legitimating processes.

The first section presents the main dynamics, organisations, forums and arenas of the global agri-food policy field. The second looks at the role of economic (non-sectoral) international organisations in the dissemination of the market referential for agri-food policies. It also describes the mechanisms these organisations use for direct and indirect imposition of the market referential in the agri-food sector. The third section looks at how sector-specialized international organisations participate in the debate and how the previously mentioned non-sectoral global organisations weight on them. The final section looks at how private regulation devices participate in the marketization trend in the field of global agri-food policy.

The global agri-food policy field, a constellation of organizations, forums and arenas

\section{Policy-making as an institutionalization process}

Public policies are institutional compromises with two main (not always aligned) dimensions: a policy discourse and a set of policy instruments (Fouilleux 2003; Lascoumes and Le Galès 2005). Such a compromise results from a process of institutionalisation of visions, values, representations and ideas (Fouilleux and Jobert 2017; Jobert 1992; Jobert and Muller 1987; Schmidt 2008). We will encompass these different elements under the generic term: 'ideas'. Obviously, ideas are defined in a wide sense, including the representations that actors have of their interests. We understand the policy-making process as a process of institutionalisation of specific ideas among various possible or existing alternatives.

In the literature, the ideational dimension of policies is referred to through various terms: referential (Jobert and Muller 1987; Muller 2005, 2015), paradigm (Hall 1993), core 
(Sabatier and Jenkins-Smith 1993) or frame (Schon and Rein 1994). These analytical concepts tend to focus the attention on policies as coherent, static and stable frameworks of references. We consider public policies as essentially multidimensional political compromises. As such, they are not necessarily coherent (Nuttal 2005). They are the result of multiple 'problematisation' and 'translation' processes (Callon 1984) which eventually end up in the institutionalisation of certain ideas into policy instruments. Yet, rather than starting from a vision of policy referential/paradigm/frames as fixed, persistent and path-dependent, we adopt a pluralistic and agonistic stance (Mouffe 2013). Policies are dynamic compromises in the making, resulting from a set of political exchanges and political deals of various types. While the policy compromise and its corresponding frame may be overall quite stable for a given period in a given policy field, it may also be modified, whether this is incrementally or radically (or in a mixed manner depending on the dimensions considered). This depends on changes in power relations between actors participating in the multiple policy deals underlying the compromise. A number of variables are likely to influence these processes, among which macro formal and informal institutions (who is in, who is out, what are considered to be suitable arguments or not, etc.) as well as micro-institutions (existing policy instruments or evaluations and assessment tools which shape the debate through feedback). Another major element is the quantity and the nature of resources put in play by the different actors, which directly shape their power and thus their respective influence on policy choices.

Our main hypothesis regarding the agri-food policy field is that it is shaped by a subordination of sectoral processes to economic ones, or by the power exercised by transversal non-specialized economic organizations on sectoral/specialized ones. This leads to a major influence of the latter on the ideas that are produced and institutionalised in the field. As will be discussed, such power is exercised through various channels, from direct constraint, to indirect softer cognitive processes. 


\section{Global agora, policy forums and arenas}

Diane Stone (2008) uses the term 'global agora' to describe the public spaces in which transnational communities and networks interact and produce global public policy. As a way to study what happens concretely on this 'agora' and how such networks and communities interact concretely, we distinguish between policy arenas and policy forums.

Policy arenas are the locus where policy decisions are bargained and taken. However, only a few ideas and policy options are under discussion at this final stage of the policymaking-process. In reality, processes of progressive selection of alternatives take place upwards, in different communities and networks of actors involving power relations and translation processes, out of which only a few survive (Callon 1986, 1991; Callon and Law 1982). We name policy forums as the communities and/or networks where policy prescriptions and instruments are discussed much before the formal/official final policy negotiations (Fouilleux 2003; Fouilleux and Jobert 2017; Jobert 1994). Forums are multiple and varied in any given policy field: academic, professional, administrative, etc. In each of these forums (which are not directly targeted at policy decisions), specific power relations exists and specific rules for constructing a valid argument apply. Policy forums are also the locus where policy evaluation and assessment tools are defined and implemented. Such elements often constitute fundamental micro-institutions of the field; they can have a key role in defining policy problems and framing the debate.

Besides institutional resources (e.g. role in decision processes, access, right to participate, right to talk, right to vote and weight of this vote, etc.), financial resources (e.g. staff costs, travel, etc.) and political resources (e.g. ability to influence deals by threatening defection), solid discursive resources are necessary to be considered legitimate participators in global policy forums and arenas. These include resources for analysis and forecasting; 
specific capacities for expertise, for the production of analytical categories and for the modelling of reality. They also include the capacity to adapt one's discourse according to the audience addressed and to build alliances with certain sections of society. Forums are particularly important places where legitimization processes occur.

Surprisingly, the manner in which international organisations position themselves in policy debates, try to exert their influence or develop strategies of legitimisation has not been well studied (Biermann and Siebenhüner 2009; Broome and Seabrooke 2012). As producers of public multilateral action (Petiteville 2016; Petiteville and Smith 2006), we consider that international organisations can be simultaneously or by turn: arenas, forums and actors in global debates and global policy fields, i.e. global arenas and forums.

Firstly, international organisations as arenas are the places where policy decisions (funding decisions, standard-setting decisions, etc.) are negotiated and taken. This mostly activates the higher political level of the organisation - intergovernmental decision bodies. Secondly, and most importantly, international organisations can be policy forums. They are spaces for debates, deliberation and confrontation of competing potential policy options, most often coordinated by bureaucrats/international civil servants. They are therefore spaces for the production of studies, for the development of public policy assessments, of benchmarking and evaluation tools, and for the dissemination of prescriptions and recommendations. These forums are active well before (upwards) the arena in the policy-making process. Compared to major negotiations that are highly publicised and mediatised, they are practically invisible, but play major roles in influencing negotiations.

Third, international organisations can also become policy entrepreneurs defending specific options in a given policy field. To do this, they develop strategies of alliance, of influence, of construction of their cognitive authority, and of legitimization. This does not 
mean that international organisations as actors are monoliths, with all members having the same opinions and moving in the same way. Often, antagonistic stances are defended by the same organisation ${ }^{\mathrm{ii}}$.

However, keeping debates alive within an organisation does not mean that there are no power relations and hegemonic options weighing on the organisation. As we will show, in the agri-food global policy field policy forums tend to be dominated by economic international organizations, as they are particularly efficient at leading debates and at producing normative policy evaluation tools and standards which are applied at the sectorial level.

\section{Non sectoral organisations as key 'first-shapers' of agri-food policies}

Policymaking is most often analysed by focusing at the sectoral level, although nonsectoral actors are often key in the process. In the agri-food policy field, three non-sectoral organisations have a key orientating role: the World Trade Organisation (WTO), the World Bank, and the Organization for Economic Cooperation and Development (OECD). Although these international organisations' do not specialise in agriculture and food they actively hold discourses with sectoral actors and influence agri-food policy through direct imposition mechanisms and softer processes of dissemination.

\section{Direct constraints on states and 'domestic' agri-food policies}

The main type actor who has led to the institutionalization of the market referential in the agri-food policy is the World Trade Organisation (WTO). For decades, agriculture was considered an exception in multilateral trade negotiations (due to its dependence to climatic conditions and the politically sensitive nature of food security) and was not discussed with the other economic sectors. However, in 1986, member states of the General Agreement on Tariffs and Trade (GATT) decided to include agriculture in the so-called Uruguay round. Since the Uruguay round, agricultural products have been considered the equivalent to 
manufactured products. This was a key decision in the history of agri-food policies because it made institutionally possible trade-offs between agriculture and industry in trade negotiations. This opened a new era characterised by a neoliberal market-oriented paradigm shift (Coleman et al. 1997; Skogstad 1998; Daugbjerg and Feindt 2018). Some authors have qualified this shift as a 'post-exceptionalism turn' (Daugbjerg and Feindt 2018). The Uruguay Round was also a step in the political history of international trade as the Marrakech agreement, eventually obtained after huge difficulties in the agriculture part of the negotiation, opened the way to the creation of the WTO in 1995. Besides the 'non-discrimination' principle, which seeks to prevent countries from taking retaliatory trade measures against others, and the Dispute Settlement Body (DSB), which has the authority to resolve trade disputes between member states, the WTO has institutionalised particularly strong constraints on national agricultural policies. They have had a direct and very concrete policy impact: in the 1990 and 2000s, a trend towards deep reform of national agricultural policies took place around the world in order to conform to the new WTO rules.

Another important constraint mechanism that has had a crucial impact on agri-food policies in the last four decades, that applies mainly to the developing world, is the conditionality system of multilateral bank loans accorded to governments. World Bank loans are a perfect illustration of it. At the beginning of the 1980s, the World Bank launched, in collaboration with the IMF, the Structural Adjustment Programmes (SAPs) and imposed these on developing countries in return for renewed loans or re-scheduling of outstanding loans. These programs required national currency devaluation, interest rate hikes, reductions in public expenditure, mass privatisations, reductions in public subsidies, and salary freezes. In agriculture, this meant maximal withdrawal of the State from all market-related instruments and activities, the elimination of tariffs and other supports to agriculture, dramatic reduction agricultural related civil servants, privatization of production, transformation and 
commercialisation units, etc. Food security was meant to be achieved through international trade of agricultural products. Practically, this resulted in an almost total abandon of the agrifood sector in global development policies and in declining funds for multilateral agricultural and rural development aid in general. This resulted in a quasi-disappearance of agri-food policies in many developing countries (notably in Africa).

In the 1990s, the extremely negative consequences of the SAPs on social and poverty levels led to strong contestation of the legitimacy of the World Bank as a development actor. Conscious of this failure, the Bank profoundly changed its discourse from 1999, turning towards the theme of poverty reduction. It also integrated the issues of equity and empowerment, aid ownership and democratic accountability of public institutions in its discourses and criteria for 'good governance'. However, the rhetorical break has hardly been visible in the policy tools proposed by the Bank, which never call into question the heart of economic orthodoxy of its previous reasoning. This is particularly clear in the agri-food field where the main discourse by the World Bank still points to more international trade in order to get the cheapest food possible.

\section{Technical assistance and training as diffusers of trade-oriented policies}

In addition to these direct constraints on states, the WTO, the World Bank and the OECD are also active at organizing the dissemination of the market referential by other softer - means through the agri-food policy field. Since the beginning of the 2000 s, most donors reallocated a part of their development aid towards trade negotiation support through 'capacity development' activities on trade and trade policy (financial support to delegations in Geneva, training of government staff in-country). This aimed at attenuating the deeply unfair functioning of the WTO (multilateral negotiations on one hand, disciplinary action by the DSB on the other hand) arising from disparities in financial, analytical and human capacities 
of the different national delegations (Coleman 2003; Narlikar 2001; Narlikar, Daunton, and Stern 2012) $)^{\mathrm{iii}}$. Similarly, many economic and trade related international organisations have developed technical assistance programmes for capacity development. The World Bank publishes and disseminates studies on trade and provides specific analytical tools (such as the World Integrated Trade Solution ${ }^{\text {iv }}$ ) and provides training. The United Nations Conference on Trade and Development (UNCTAD) also provides technical assistance, carries out 'consensus building activities' (in Geneva) and provides training on international trade and trade policy issues.

The United Nations Food and Agriculture Organisation (FAO) also instituted programs for developing capacities in international trade (statistical data collection and processing) from the early 2000s. Similarly, NGOs specialised on agriculture and agriculture policy also provide training and support to countries to develop their positions and strategies in negotiations. While formally working to redress asymmetries of power, these trainings and 'knowledge updates' have a notable performative effect: they contribute directly to the dissemination of the trade referential among administrative elites in the developing countries and consume a significant part of development aid, which consequently does not go to other pressing issues in the agri-food field. Therefore, the feature of international trade is promoted as a crucial (if not unique) perspective for agricultural development.

\section{The World Bank, a market-oriented agri-food policy thinker for developing countries}

The World Bank's influence in the field of agri-food is based largely on its status as the reference in development economics worldwide. The Bank has built up this central status since the 1980s in close relation to the academic forum in economics and has actively been seeking to preserve its role since then. Even at the end of the 1990s, when the Bank was suffering criticism, its discursive shift allowed the organisation to overcome the crisis of 
legitimacy and reaffirm and reinforce its cognitive leadership on the academic scientific forum (Cling, Razafindrakoto, and Roubaud 2011).

This status is built on a particularly well-developed network and stable relations with the worlds of academia, research and think-tanks (Stone 2013b). It is also founded on intense publication activity by Bank staff, the funding of vast programmes of research and expertise, and on the recruitment of young graduates to specific programmes. The World Bank is thus a direct and powerful actor in the scientific/academic forum of development studies, which tends to be restricted to the discipline of economics in its standard neoclassical approach. In effect, despite a recent rehabilitation of the role of states and public policy in the Bank's discourse and its new attention to issues of participation and accountability, social sciences other than economics remain largely marginalised in the Bank (or are present in very normative forms).

While using the 'buzzwords' of the day (successively in the last decades: poverty reduction; participation / transparency / ownership; and sustainable development), the Bank's focus regarding agri-food policies are essentially oriented towards trade liberalisation and privatisation. In addition to the (non)vision of agriculture and rural development contained in the agricultural structural adjustment programs described above, the Bank's discourse on food security is quite emblematic of its influence. Notably inspired by the work of the Nobel Prize economist Amartya Sen, the World Bank emerged as a powerful actor in the agri-food field after the publication of its 1986 annual World Development Report (the main flagship publication of the Bank), in which it proposed a new definition of food security based on the notion of access. In this individualized neoliberal approach (Jarosz 2011), food security was not only related to the ability to produce food, but rather to the ability to pay in order to access food. In this, the food must be as cheap as possible and not necessarily produced where it is sold. This view was progressively adopted by actors in the agri-food policy field and was 
institutionalised in the Rome declaration in $1996^{\mathrm{v}}$. In terms of institutional and political influence, the emergence of the World Bank as a main actor in the global agricultural policy field in the 1980s has considerably weakened the position of the UN specialised organisations of the field, especially the FAO.

In 2008, the World Bank released a new annual report entitled Agriculture for Development. In this report the Bank acknowledges the mistake of having abandoned this key sector for poverty reduction and presents agriculture as a main engine of development. However, despite an undeniable change in the narratives and general discourse of the report, the policy solutions proposed remain particularly stable, focused principally on the issues of liberalisation, market access and international trade (Oya 2009). Put in the context of the period, the report very clearly illustrates the high degree of disconnectedness between the World Bank ideological work and the concrete reality on the ground. In 2007/2008, a big agricultural price crisis emerged due to low cereal stocks, high demand for biofuels, various export bans, speculation, provoking food riots around the developing world. There was nothing in the World Bank's report that foresaw this looming price crisis nor the urban riots that followed. Rather, the Bank focused on promoting its report and thus missed the opportunity to take the initiative to coordinate a response to the crisis. This by the way gave the opportunity to the FAO to temporarily re-emerge as an institutional voice in the global agri-food policy field as it took the opportunity of an international summit that was planned for months on sustainable development and global warming, to take the political lead on the food price crisis. The FAO was thus prompt to relaunch its traditional productionist mantra that we need to produce more to feed the world (Fouilleux, Bricas, and Alpha 2017). A mantra which the World Bank has now adopted; convinced by a number of private actors with direct interests in the field, among which are the Bill and Melinda Gates Foundation and the Rockefeller Foundation) (McKeon 2015). 


\section{The OECD, the neoliberal antechamber for agri-food policy liberalisation}

The Organisation for Economic Cooperation and Development, created in 1961, is a very discrete organisation that holds no large gatherings, no negotiation rounds and no highly publicised summits. But, in reality it is a space of both constant negotiation and intense intellectual activity, whose objectives are none other than the definition of public policy norms and their promotion among member states (Marcussen 2001, 2004; Porter and Webb 2007). The OECD's influence goes well beyond its member states. Through its Development Assistance Committee, the OECD influences aid and aid policies, which in turn affect national agricultural policies in developing countries.

In a manner very similar to the World Bank, the work of the OECD is based on intense exchanges and strong links with custodians of the dominant paradigm of academic economics. OECD staff most commonly hold post-doctorate degrees in economics. They also include academics and researchers on sabbaticals from their respective institutions. Publishing activity of economic and statistical nature is intense, and the organisation's periodicals are reputed by the academic world. This close link with the academic world is one of the main foundations for the legitimisation of the organisation in its policy work. Enjoying legitimacy, OECD's influence is further exerted through the development and dissemination of tools for analysing, evaluating and benchmarking public policies, in all sectors. The work of the OECD is articulated around events to discuss academic work, around benchmarking exercises (using ad hoc evaluation instruments), as well as the peer-reviewing of policies of member states by other member states.

The OECD has had a very active role in spreading a neoliberal vision of agricultural

policy, beginning in the 1980s. In response to a ministerial demand in 1982 to clarify the links between instabilities on agricultural international markets and national policies, the 
agriculture services of the OECD (in Paris) invented and disseminated new agriculture policy evaluation tools. The Producer Subsidy Equivalent (PSE) and the Consumer Subsidy Equivalent (CSE) allow the comparison of agriculture policies of different countries, and the measurement of their respective distortion effects on international agricultural trade. These tools, which were created and fine-tuned in close relation with agricultural academic economists, convey a vision of agricultural policy in which the essential criteria is no longer based on internal or sector-related objectives established nationally, but rather on its effects on international trade. They allow ranking states for their more or less trade distorting agricultural policies. These tools have had a huge political impact. First, they provided convincing arguments to the countries that where favourable to the inclusion of agriculture in the Uruguay Round. More fundamentally, the wide diffusion and dissemination of OECD analysis, based on the PSE/CSE calculus in the 1980s and 1990s, deeply transformed the terms of the global debate on agriculture during the following decades in ways that have rapidly become hegemonic at the global level (Fouilleux 2000, 2003). Almost forty years later, the PSE/CSE estimations still feature prominently in global agricultural debates.

In the late 1990s and 2000s, the OECD heavily weighted on the international debate regarding multifunctionality of agriculture and how and why agricultural policies should or should not take into account this issue (see Fouilleux, 2004). At the same period, the OECD has also been a major promoter of the concept of bio-economy, which has been diffusing worldwide (particularly in the EU) with crucial implications in the agri-food field. The bioeconomy presents itself as a key driver for sustainable economic growth, through the substitution of fossil fuels with new biomass uses. Indeed the bio-economy discourse has emerged in the OECD as an engine for the promotion of biotechnologies in all sectors of economic and social life and in particular, agriculture. It promotes a vision of agriculture as a sector of massive production and trade of biomass for a diversity of uses (biomaterials, 
biotechnologies, biofuels, etc.) not only food (Pahun, Fouilleux, and Daviron 2018). Such a vision sharply contrasts with visions of agriculture promoting small-scale farms and territorial embeddedness (Levidow, Birch, and Papaioannou 2012). The bio-economy case also illustrates the active role played by the European Commission as a transmission belt of prescriptions developed at the OECD to the European policy arena: indeed, the bio-economy feature has become a main area of EU agriculture research and is increasingly shaping the discourse in the field of agri-food (Pahun et al. 2018).

\section{A sectorization process subjected to hegemonic market-oriented organisations}

Beside the activism of transversal organisations such as the WTO, the OECD and the World Bank in the diffusion of marketization of agri-food policy, sectoral organizations also play an important role. This is either due to their own adhesion to the neoliberal paradigm, or, more often, due to their inability to produce any counter-discourse.

\section{The FAO and its discursive weaknesses ${ }^{\mathrm{vi}}$}

The main international organizations of the agri-food policy field are the Food and Agriculture Organization (FAO), the World Food Programme (WFP) and the International Fund for Agricultural Development (IFAD). In the 1980s, in parallel to the increasing influence of the World Bank, these sectoral organizations suffered a progressive delegitimating process. As an illustration, in the 1980's, the World Food Council (WFC), an organization created as a coordinating body for national ministries of agriculture to fight against malnutrition and hunger through the development of new agricultural techniques, was suspended (Shaw 2010). Another illustration lies in the decreasing budget of the FAO since then, and more generally, the decreasingshare of agriculture in official development assistance (both multi and bi lateral). The FAO was criticized on all sides and its political influence was diminished in the international arena. A 'first-ever independent external evaluation (IEE) of 
FAO in its sixty-year history' was launched in 2005 with the frame of the UN. In September 2007, the report called for a deep reform of the organization. Formally, the FAO 'promotes, facilitates and supports evidence-based policy dialogue at the global, regional, and national levels. FAO is itself the world's leading global forum for policy debate on the role of food and agriculture in fostering sustainable development ${ }^{\text {vii }}$. However, the organisation has had difficulties to projecting a clear vision of agricultural policies to the international community and in particular of food security policies, the heart of its mandate. As a result, it has had a tendency to restrict its work to technical assistance and to overlook the political dimension of policies and has generally followed the trade-oriented mainstream in its policy discourse (Fouilleux 2009) which fitted easily with its productionist mantra (Fouilleux et al. 2017).

The inability of the FAO 'to play the forum game' (Marcussen 2001) points to various issues. First, some of its most powerful member states adopt internal neutralisation strategies in order to control its activities and discourses. Big exporter countries promoting international trade and opposing discourses favouring state intervention in agriculture, such as the United States and Australia, have often developed such strategies within FAO. This prominently occurred in the 2000s, when the FAO was completely excluded from the global debate on the multifunctionality of agriculture, in favour of the OECD. In fact, multifunctionality of agriculture was considered a crucial issue in the frame of the negotiations on the WTO as it was mobilisedby countries as the European Union or Japan as an argument in favour of public support to farmers. Although the FAO was developing an analytical study on The Roles of Agriculture at that time, it was considered too subversive was thus 'silenced' (i.e. the organisation had to reduce the scope of the communication and diffusion of the study, both internally and externally). Various interviewees involved in this project affirm that they were limited in their work, due to its 'political' nature in relation to WTO on-going negotiations (see Fouilleux 2004, 2009). 
Second, in light of the legitimisation academic economics provided the previously mentioned organisations, the FAO had a harder time legitimating its economic arguments. Generally speaking, the weakness of the FAO in relation to policy, might be explained by an 'inferiority complex' of the organisation's economists with respect to those of the World Bank, who are much better integrated in the academic forum. Surprisingly however, the economist at the FAO appear to under-utilise their comparative advantages, in particular, their knowledge of the field and their strong local networks (which the Bank's economists often lack) to add value to their work. These elements are not seen as legitimating ones in the field of development public policy, while theory and academic recognition is. Moreover, there is a sort of brain drain in favour of the World Bank, which represents power, academic prestige and greater financial reward all at once. The World Bank attracts the best international consultants (a consultant will always prefer a contract offered by the World Bank rather than one, much less paid, offered by FAO), the most renowned academic economists (it is far more prestigious to work with "the Bank" rather than with FAO), as well as the most promising young economists seeking positions with the best prospects to launch their careers.

Third, its lack of discursive resources makes FAO incapable of defending alternatives by itself or even in alliance on an international level. Often when actors try to push for alternatives through alliances of this type with the FAO they are often find their initiatives killed at birth. Indeed, various academics have demonstrated that the FAO is constrained to following the liberal mainstream, without the capacity to put forward alternative visions (Fouilleux 2009; Tomlinson 2013). This is what appears to currently be occurring in relation to agriculture policy evaluation for developing countries. For some years now, FAO staff have been attempting to develop innovative approaches in agricultural policy analysis for developing countries with their Monitoring and Analysing Food and Agricultural Policies (MAFAP) program ${ }^{\text {viii }}$. Unfortunately, this has be seen by the World Bank and the OECD as a 
potential threat/challenge to their hegemony in the field of agricultural policy analysis. In order to have any influence the FAO has had to adopt a mainstream economic framework and accept the direct chaperonage of the World Bank and the OECD as members the steering committee of the project.

In sum, the specialised agri-food organisations show great difficulty (or no real will) to assemble the necessary resources to effectively support alternative positions to the liberal mainstream policy discourse in the agri-food field.

\section{Standardisation agencies for international trade}

The efficiency of international organisations in imposing their will in matters of public policy regulation depends on the themes that they address and the level of potential threat their discourse poses to dominant neoliberal orthodoxy. As technical standard-setters for the WTO with the goal of harmonising international trade, some organizations and suborganizations in the agri-food policy field are well placed in the global scene. They are considered by influential and powerful states as arenas where it is important to be active and present.

The Codex Alimentarius, a joint FAO-World Health Organisation (WHO) body dedicated to defining international food standards was in the past moribund. Its standards, were not compulsory and were never applied. However, the Codex Alimentarius was designated in 1994 as the WTO standard-setting agency for food (its standards are now used as reference points for WTO bargains and arbitrages) and has enjoyed a high profile ever since (Büthe 2009).

The World Organisation for Animal Health (OIE) is another example. The very existence of this organisation in the agri-food global policy field, atypical both for its position in the international system (outside of the United Nations system) and for its small size (83 
professionals in all), was threatened on several occasions. However, it not only survived but was able to progressively widen its mandate. The fact that it was chosen by the WTO in 1994 as the global standard-setting organisation in the field of animal disease and zoonoses partly explains this. Today the OIE is internationally recognised as existing on the same level as UN organisations and has progressively established itself as indispensable in the global management of emerging infectious diseases, to the expense of the FAO, its main competitor in the animal health policy field (Figuié 2014). Beyond its actual role in standard-setting for trade, the way in which the OIE treats certain animal diseases and the tools that it disseminates to states to manage them reveals the strong influence of a trade-oriented paradigm within the organisation, as is evident in its management of the foot-and-mouth disease (Figuié and Fouilleux 2013).

The rise of private regulation. How market-based instruments increasingly shape the agri-food policy field

As many IR authors have underlined, international organisations are no longer the only actors in the production of public policies. As Djelic and Sahlin-Andersson (2006) point out, the global policy space has evolved from: an essentially international configuration to a transnational one, in which interactions between organisations in state and non-state sectors are dense and multifunctional, in which the attribution of responsibilities between organisations can shift, and in which the limits between what is public and private are increasingly blurred. For more than two decades, there has been a process of:

fundamental reconstitution of the global public domain away from the one that equated the 'public' in international politics with states and the interstate realm, to one in which the very system of states is becoming embedded in a broader, albeit still thin 
and partial, institutionalized global arena concerned with the production of global public goods. (Ruggie 2004, p. 2)

The increasing delegation by states and international organisations of more and more responsibilities to private actors does not however signify complete deregulation. On the contrary, the phenomena of transnationalisation is leading to a proliferation of rules (LeviFaur 2005). Certain non-state actors are thus able to cooperate beyond borders to establish rules and behaviour standards that are accepted as legitimate by agents that are not involved in their definition, thus creating new forms of global authority (Graz and Nolke 2007). Private actors also actively diffuse market oriented ideas (Stone 2013a). The various private mechanisms and devices implemented are more or less distant from public authorities, but they always maintain exchanges with national administrations and international organisations in a number of ways (Verbruggen 2013).

The agri-food policy field is an emblematic example of the increasing importance of private and public-private regulation mechanisms, with a proliferation of private standards and rules, which de facto become public, characterising a governance culture based on 'soft rules' without any associated legal sanctions (Levi-Faur 2005). These new rules, which are market based, reorganise and reorder the referential through processes of permanent negotiation and renegotiation often creating tensions and disputes (Djelic and Quack 2010). Private transnational regulation has the market at the heart of its framework, both as a point of departure and as the ultimate goal (Busch 2011). Its preferential instruments, voluntary standards, serve either for market segmentation purposes or as assurance tools within the value chain. Through third party certification and accreditation systems they multiply, expand and connect markets (Fouilleux and Loconto 2017). In agri-food there has been three main waves of private voluntary standards (Fouilleux 2012). The first were pushed by the civil society in order to contest industrial agriculture and globalization (organic farming and fair 
trade) in terms of market share these have tended to remain marginal. The second and the third ones are more interesting for our argument. These are food safety retailers' standards on the one hand and sustainability standard promoted by the food processing industry and financial sector on the other.

The first type of private voluntary standards that has become mainstream in the agrifood policy field are "retailer" standards that focus on food safety. Such standards (e.g. GlobalGAP and IFS3), are utilised by stakeholders involved in large-scale retailing as ways to ensure the food safety of the products they buy to sell to final consumers - they are a way to transfer the responsibility of food safety from the retailers to the producers. GlobalGAP standards are emblematic. They were first developed in 1997 under the name of EurepGAP (Euroretailer produce working group for good agricultural practices) and were originally to be applied exclusively to food safety issues (they now include - though marginally - sustainable development along with social, environmental and ethical concerns). The standards resulted from an initiative of the key stakeholders involved in European supermarkets, who participated in the Eurep working group, under strong British influence from companies such as Tesco and Sainsbury's. These private standards are not a priori obligatory and their application remains theoretically voluntary, but the fact that all major retailers demand such standards explains their very rapid extension and widespread implementation. In fact, for many purposes, they have replaced public standards (Jaffee and Henson 2004). Moreover, because of the extent of their application, EurepGAP standards are often assumed to be obligatory by countries that export to the European Union. To avoid confusion with mandatory public standards the EU pushed for the name to be changed to GlobalGAP, which was done in September 2007. In addition, due to the market power of retailer standards, they are more often used as reference for governments: they are sometimes used as explicit objectives or as a 'basis' for national and international public policy. To assist producers with 
upgrading operations and practices and to 'facilitate their market access' courses have been funded and delivered (and grants are targeted) by public officials designed to help private actors implement these privately developed standards.

The second type of mainstream voluntary standards developed in the last two decades aim at ensuring the sustainability of raw material South-North value chains (Marx and Wouters 2014). Initially these applied to forests (FSC - Forest Stewardship Council, 1993) and then fisheries (MSC - Marine Stewardship Council, 1999). This has extended to textiles and mining among others. In general, voluntary sustainability standards have multiplied in the last decades for agricultural commodities originating in the tropics and traded on international markets. Examples include the Roundtable on Sustainable Palm Oil (RSPO, 2003), for Responsible Soy (RTRS, 2005), for sugar cane (BSCI, 2006), biofuels (RSB, 2007), cotton (BCI, 2007), cocoa and coffee. These organisations describe themselves as private and explicitly outside the realm of public authorities. They have been launched by processing industries and banks, as a response to the social movements and boycott threats that took place in Northern Europe, denouncing the conditions of production of most of the agricultural commodities imported from Southern countries and their negative environmental effects, namely massive deforestation (Bartley 2007). Contrasting with retailers' standards, which are clearly targeted at defending the retailers' interests in the value chains, voluntary sustainability standards, pretend to include all the stakeholders of the concerned value chains. They have institutional attributes of democratic and fair functioning, and claim inclusiveness and equal participation. Their decision structures include different categories of stakeholders, most often organized in three main groups (producers; trade/industry/finance; social and environmental NGOs), and theoretically involve inclusive policy-making. In practice, their inclusiveness is questionable (Cheyns 2011; Fouilleux 2013). Many NGOs denounce them as social and environmental washing, and as strategic instruments used by big multinationals in 
order to protect their unsustainable business models as long as possible from any legal obligations and to maintain or increase further their market-shares.

Although private, those standards nourish intense relations with public authorities. Firstly, public actors are sometimes their direct instigators, feature among their members, or are significant funders (several bilateral European cooperation agencies, even the World Bank, through the IFC). This is the case of several sustainability roundtables, including those on soya, palm oil and cocoa. Secondly, international organisations such as the International Trade Consortium (a joint WTO-UNCTAD agency), the FAO and the UNCTAD are heavily involved in the production of knowledge on voluntary standards and actively contribute to their promotion. Five UN agencies created the United Nations Forum for Sustainability Standards (UNFSS) specially dedicated to this task. Such activities support directly or indirectly the development of private market instruments, with significant performative effects, notably on the governments of developing countries. These are 'imposed' (particularly by industrial players in importer countries) to develop and support the implementation of such instruments, often without any analysis of the needs or real opportunities for the country in question.

Third, these private regulation organisations are careful not to create any threat to the international order as embodied by the transversal economic organisations presented earlier in this chapter. We have shown elsewhere, with the example of the International Social and Environmental Accreditation and Labelling Alliance (ISEAL), the private global organisation for voluntary sustainability standards (Loconto and Fouilleux 2014). In its discourses and regulations (ISEAL codes), ISEAL systematically refers to the WTO and ISO as the points of reference and refuses to discriminate / distinguish standards on criteria other than their procedures (i.e. neither their substantive content nor degree of impact on the ground can be used to compare their member standards). As a movement with origins in civil society, 
ISEAL claims to fight for greater respect of social and environmental rights in globalisation. However, ISEAL's activities appear more as a form of allegiance to international trade as the end goal of development, in strict continuity with the discourses of the WTO and the World Bank. From this perspective, voluntary sustainability standards are a perfect example of the hijacking of criticism, whereby a mechanism intended to repair or counter the adverse effects of international trade ends up becoming an active instrument in its (re)legitimisation.

\section{Conclusion}

This chapter has described the global agri-food public policy field as a series of arenas (where public policy decisions are taken), forums (where public policy assessment, benchmarking and evaluation tools and/or policy prescriptions are formulated by experts), and actors interacting in these arenas and forums to produce policy instruments and discourses. Among these are to core types of international organisations; transversal economic ones on the one hand (WTO, World Bank, OECD) and specialised / sectoral ones on the other hand (FAO, WFP, IFAD, Codex Alimentarius, OIE, UNFSS). We have highlighted a clear and relatively strict division of labour between those international organisations, the former formulating neoliberal trade oriented global policy prescriptions and the latter applying them. We have also described the intricacy of these international organisations and private regulatory devices, such as private voluntary standards (retailers standards for food safety and multi-stakeholder standards for sustainability in particular). The chapter has also exposed four concomitant processes that contribute directly to the hegemony of the market referential in global agri-food policy debates.

The first is based on imposition. The WTO, which is a form of the direct application of these ideas in the realm of global trade policy, constitutes the central arena for the construction of rules that place constraints on national public policies, thereby imposing the 
market paradigm on nation states and their agri-food policies. The second is a dissemination process involving the production of studies, analysis, reports, and policy evaluation tools. This process has been actively led by the World Bank (for developing countries) and the OECD (for developed countries). These two economic and financial organisations feed the agri-food policy debate, with specifically market and trade oriented arguments and policy prescriptions. Both gain legitimacy as a result of being close to the academic economics forum and from their strong presence in the academic world (publications, studies, research programmes). They participate actively in the development of concepts and of policy evaluation and benchmarking tools that promote liberalisation and forms of private and public-private regulation.

The third process has to do with the nature of the sectorisation that goes on at the international level, and more particularly with the ability of agri-food specialized organizations to define their own path for policies. We have shown that confronted with the liberal market referential that has been forged and disseminated on a large scale by economic and financial organisations, agri-food specialised international organisations, and in particular the FAO, appear as particularly weak and unable to propose an alternative narrative. Their legitimacy is diminished by low academic recognition and weak integration in relevant debates. This has not been compensated for by strong alliances with civil society. Only some find their place in the global scene by acting as standard-setting agencies for the WTO.

Fourth, the hegemony of the market referential is further embedded through a process of privatisation. We have highlighted the extent to which the market is at the heart of the way issues are addressed and the instruments developed by private regulatory organs in the field. We have also mentioned the forms of allegiance of these to public organisations who are custodians of the market referential. In this sense, the rise of private regulatory organisations does not so much arise from a form of complete renewal of world order, but rather presents a 
form of continuity and extension of the global market referential embodied by the previously existing international institutions and their hierarchy. Just like what we described for the World Bank and its use of buzzwords, the multiple voluntary standards initiatives aimed at 'sustainability' are global figures for incorporating socio-ecological criticism. They participate in a direct way to the progressive adaptation of the marketisation discourse to its critics, while bringing only marginal amendments to neoliberal policies without ever calling to question their fundamentals.

Undoubtedly, future research should be targeted at getting a better picture of the forms of resistance and renewal of criticism on a global level. Such research should analyse the dynamics of national influence within the concerned international organisations and in the deliberative forums and negotiation arenas. As we have illustrated, member states of international organisations may use strategies to support or neutralise certain analytical and discursive activities according to their own interests and visions of the world. Similarly, we observe differences in the influence of American or European firms in a number of public or private forums and arenas, and these must definitely be more specifically analysed. The recent changes in the positioning of the United States on the international arena and the rise of China as a major trade oriented actor may also open new paths of marketization and new power relations among and between organisations, with new forms of interactions with bureaucrats in the organizations. Poorest countries, just like civil society or social movements' organisations, which do not structurally have a voice due to a lack of analytical and discursive resources in both public and private regulation processes, shall remain dominated but may find new venues to express their visions. The question is very much where (which arena? Which forum?) and how (which groups of actors? Which political exchanges?) power relations and hierarchies may change in the future.

\section{Footnotes}


i The analysis presented in this chapter is based on both a literature review and the analysis of empirical data collected since the late 1990s through a long term continuous research implication on the ground, including participant observations in international meetings at EU and international level, hundreds of interviews with actors, and many other research and expertise activities in the field.

ii For example, the Food and Agriculture Organization regularly issues reports that promote antagonistic normative visions of agriculture and agricultural policies. For example in 2011 two reports were published within the space of a few months respectively promoting the use of genetically modified crops for developing countries (FAO 2011, Biotechnologies for Agricultural Development, Rome) and promoting organic farming (FAO 2011. Organic agriculture and climate change mitigation. A report of the Round Table on Organic Agriculture and Climate Change. December 2011, Rome).

iii The Doha Development Agenda Global Trust Fund was created in 2003 with a target budget of 24 million Swiss Francs (WTO Press release, Press/360, 22 October 2003)

${ }^{\text {iv }}$ http://wits.worldbank.org/about_wits.html

${ }^{\vee}$ At the World Food Summit in November 1996, food security was defined as existing when 'all people, at all times, have physical and economic access to sufficient safe and nutritious food that meets their dietary needs and food preferences for an active and healthy life' (Rome Declaration on World Food Security). The definition still applies.

${ }^{\text {vi }}$ The empirical data used in this chapter gathers observations made while working in the FAO as a visiting policy officer between 2003-2006, interviews and participant observations in the frame of different research and expertise projects with this organization, and participation to 5 annual conferences of the World Committee for Food Security (and related events).

vii http://www.fao.org/policy-support/en/, visited 2019/05/09.

viii http://www.fao.org/mafap/accueil-du-sapaa/fr/

\section{References}


Bartley, T. (2007). Institutional emergence in an era of globalization: The rise of transnational private regulation of labor and environmental conditions. American Journal of Sociology, 113(2), 297-351.

Biermann, F., and Siebenhüner, B. (2009). The role and influence of international bureaucracies: Setting the stage. In F. Biermann and B. Siebenhüner (Eds.), Managers of global change: The influence of global international bureaucracies (pp. 1-14): Massachusetts Institute of Technology.

Broome, A., and Seabrooke, L. (2012). Seeing like an international organisation. New Political Economy, 17(1), 1-16.

Busch, L. (2011). Standards: Recipes for reality. Cambridge, MA: MIT Press.

Büthe, T. (2009). The politics of food safety in the age of global trade: The codex alimentarius commission in the sps-agreement of the wto. In C. Coglianese, A. Finkel, and D. Zaring (Eds.), Import safety: Regulatory governance in the global economy (pp. 88-109): University of Pennsylvania Press.

Callon, M. (1984). Some elements of a sociology of translation: Domestication of the scallops and the fishermen of st brieuc bay. The Sociological Review, 32(S1), 196-233.

Callon, M. (1986). Some elements of a sociology of translation: Domestication of the scallops and the fishermen of st brieuc bay. In J. Law (Ed.), Power, action and belief. A new sociology of knowledge? (pp. 196-233). London: Routledge \& Kegan Paul.

Callon, M. (1991). Techno-economic networks and irreversibility. In J. Law (Ed.), A sociology of monsters: Essays on power, technology and domination (pp. 132-163). London: Routledge.

Callon, M., and Law, J. (1982). On interests and their transformation: Enrolment and counterenrolment. Social Studies of Science, 12(4), 615-625.

Cheyns, E. (2011). Multi-stakeholder initiatives for sustainable agriculture: The limits of the 'inclusiveness' paradigm. In S. Ponte, P. Gibbon, and J. Vestergaard (Eds.), Governing through standards (pp. 210-235). New York: Palgrave Macmillan.

Cling, J.-P., Razafindrakoto, M., and Roubaud, F. (2011). La banque mondiale, entre transformations et résilience Critique internationale, 53(4), 43-65.

Coleman, W. (2003). Globality and transnational policy-making in agriculture: Complexity, contradictions and conflict. Retrieved from Hamilton, Canada:

Djelic, M.-L., and Quack, S. (2010). Transnational communities. Shaping global economic governance. New York: Cambridge University Press.

Djelic, M.-L., and Sahlin-Andersson, K. (2006). Transnational governance. Institutionnal dynamics of regulation. New-York: Cambridge University Press.

Figuié, M. (2014). Towards a global governance of risks: International health organisations and the surveillance of emerging infectious diseases. Journal of Risk Research, 17(4), 469-483.

Figuié, M., and Fouilleux, E. (2013). How much severe is a disease? The social construction of the foot and mouth disease. Paper presented at the ESA/ISA mid term conference "Risk and Uncertainty: Ontologies and Methods", University of Amsterdam, The Netherlands.

Fouilleux, E. (2000). Entre production et institutionnalisation des idées, la réforme de la politique agricole commune. Revue française de science politique, 50(2), 277-305.

Fouilleux, E. (2003). La pac et ses réformes. Une politique à l'épreuve de la globalisation. Paris: L'Harmattan.

Fouilleux, E. (2004). Cap reforms and multilateral trade negotiations: Another view on discourse efficiency. West European Politics, 27(2), 235-255.

Fouilleux, E. (2009). À propos de crises mondiales... Quel rôle de la fao dans les débats internationaux sur les politiques agricoles et alimentaires ? Revue française de science politique, 59(4), 757782.

Fouilleux, E. (2012). Sustainable voluntary standards: Towards privatized regulation in the food and farm sector? In P. Jacquet, R. Pachauri, and L. Tubiana (Eds.), Development, the environment and food: Towards agricultural change? (pp. 215-225). New Dehli: TERI Press. 
Fouilleux, E. (2013). Normes transnationales de développement durable. Formes et contours d'une privatisation de la délibération. Gouvernement et Action Publique, 2(1), 93-119.

Fouilleux, E., Bricas, N., and Alpha, A. (2017). 'Feeding 9 billion people': Global food security debates and the productionist trap. Journal of European Public Policy, 24(11), 1658-1677.

Fouilleux, E., and Jobert, B. (2017). Le cheminement des controverses dans la globalisation néolibérale. Pour une approche agonistique des débats de politique publique. Gouvernement et Action Publique, 6(3), 9-36.

Fouilleux, E., and Loconto, A. (2017). Voluntary standards, certification, and accreditation in the global organic agriculture field: A tripartite model of techno-politics. Agriculture and Human Values, 34(1), 1-14.

Graz, J.-C., and Nolke, A. (2007). Transnational private governance and its limits. London: Routledge.

Hall, P. A. (1993). Policy paradigms, social learning, and the state: The case of economic policymaking in britain. Comparative politics, 25(3), 275-296.

Hoffman, A. J. (1999). Institutional evolution and change: Environmentalism and the u.S. Chemical industry. The Academy of Management Journal, 42(4), 351-371.

Jaffee, S., and Henson, S. (2004). Standards and agro-food exports from developing countries: Rebalancing the debate. Retrieved from Washington, DC:

Jarosz, L. (2011). Defining world hunger: Scale and neoliberal ideology in international food security policy discourse. Food, Culture and Society: An International Journal of MultidisciplinaryResearch, 14(1), 117-139.

Jobert, B. (1992). Représentations sociales, controverses et débats dans la conduite des politiques publiques. Revue française de science politique, 42(2), 219-234.

Jobert, B. (1994). Le tournant néo-libéral en europe. (J. Bruno Ed.). Paris: L'Harmattan.

Jobert, B., and Muller, P. (1987). L'état en action. Politiques publiques et corporatismes. Paris: PUF.

Lascoumes, P., and Le Galès, P. (2005). Gouverner par les instruments: Presses de Sciences po.

Levi-Faur, D. (2005). The global diffusion of regulatory capitalism. The Annals of the American Academy of Political and Social Science, 598(1), 12-32.

Levidow, L., Birch, K., and Papaioannou, T. (2012). Eu agri-innovation policy: Two contending visions of the bio-economy. Critical Policy Studies, 6(1), 40-65.

Loconto, A., and Fouilleux, E. (2014). Politics of private regulation: Iseal and the shaping of transnational sustainability governance. Regulation \& Governance, 8(2), 166-185.

Marcussen, M. (2001). The oecd in search of a role: Playing the idea game. Paper presented at the European Consortium for Political Research Conférence, Grenoble, France.

Marcussen, M. (2004). The organization for economic cooperation and development as ideational artist and arbitrator: Reality or dream? In B. Reinalda and B. Verbeek (Eds.), Decision making within international organizations (pp. 90-105). London and NY: Routledge.

Marx, A., and Wouters, J. (2014). Competition and cooperation in the market of voluntary sustainability standards. Retrieved from Geneva:

McKeon, N. (2015). Food security governance. Empowering communities, regulation corporations. London and New York: Routeledge.

Mouffe, C. (2013). Agonistics. Thinking the world politically. London, New York: Verso.

Muller, P. (2005). Esquisse d'une théorie du changement dans I'action publique. Structures, acteurs et cadres cognitifs. Revue française de science politique, 55(1), 155-187.

Muller, P. (2015). La société de l'efficacité globale. Comment les sociétés modernes se pensent et agissent sur elles-mêmes. Paris: PUF.

Narlikar, A. (2001). Wto decision-making and developing countries. Retrieved from Geneva:

Narlikar, A., Daunton, M., and Stern, R. M. (2012). The oxford handbook on the world trade organization: Oxford University Press.

Oya, C. (2009). The world development report 2008: Inconsistencies, silences, and the myth of 'winwin'scenarios. The Journal of Peasant Studies, 36(3), 593-601. 
Pahun, J., Fouilleux, È., and Daviron, B. (2018). De quoi la bioéconomie est-elle le nom? Genèse d'un nouveau référentiel d'action publique. Natures Sciences Sociétés.

Petiteville, F. (2016). Les organisations internationales dépolitisent-elles les relations internationales? Gouvernement et Action Publique(3), 113-129.

Petiteville, F., and Smith, A. (2006). Analyser les politiques publiques internationales. Revue française de science politique, 56(3), 357-366.

Porter, T., and Webb, M. (2007). The role of the oecd in the orchestration of global knowledge networks. Paper presented at the Canadian Political Science Association annual meetings, Saskatoon, Saskatchewan, Canada.

Ruggie, J. G. (2004). Reconstituting the global public domain - issues, actors, and practices. European Journal of International Relations, 10(4), 499-531.

Sabatier, P. A., and Jenkins-Smith, H. C. (1993). Policy change and learning: An advocacy coalition approach: Westview Pr.

Schmidt, V. (2008). Discursive institutionalism: The explanatory power of ideas and discourse. Annual Review of Political Science, 11, 119-135.

Schon, D. A., and Rein, M. (1994). Frame reflection: Toward the resolution of intractable policy controversies: Basic Books.

Shaw, D. J. (2010). The world food council: The rise and fall of a united nations body. Canadian Journal of Development Studies/Revue canadienne d'études du développement, 30(3-4), 663694.

Stone, D. (2008). Global public policy, transnational policy communities, and their networks. Policy Studies Journal, 36(1), 19-38.

Stone, D. (2013a). Knowledge actors and transnational governance. The public-private poliy nexus in the global agora. Basingstock, New York: Palgrave Macmilan.

Stone, D. (2013b). 'Shades of grey': The world bank, knowledge networks and linked ecologies of academic engagement. Global Networks, 13(2), 241-260.

Tomlinson, I. (2013). Doubling food production to feed the 9 billion: A critical perspective on a key discourse of food security in the uk. Journal of Rural Studies, 29, 81-90.

Verbruggen, P. (2013). Gorillas in the closet? Public and private actors in the enforcement of transnational private regulation. Regulation \& Governance, 7(4), 512-532. 